Debreceni Jogi Múhely 2021. (XVIII.) 1-2.

Debreceni Egyetem, Állam- és Jogtudományi Kar, Debrecen

(University of Debrecen, Faculty of Law, Debrecen)

DOI 10.24169/DJM/2021/1-2/1

Leen Bakerjian

PhD student

University of Debrecen, Géza Marton Doctoral School of Legal Studies

\title{
Cross-Border MERgERS AND ACQUISITIONS IN LIGHT OF THE EUROPEAN REGULATORY FRAMEWORK
}

Debreceni Jogi Múhely, 2021. évi (XVIII. évfolyam) 1-2 szám (2021. szeptember 1.)

DOI 10.24169/DJM/2021/1-2/1

Abstract: This paper will discuss the role that Mergers and Acquisitions play in the global economy. It will deliberate on the challenges, benefits and issues of the implementation of these transactions in terms of legality, society and culture. It also contains an empirical enquiry that investigates the application of Mergers and Acquisitions in the presence of different social and cultural working environments. It also demonstrates attempts of entering into such transactions with incorrect intentions such as domination and the negative outcomes of such approach.

Throughout this work, I will investigate the legal instruments governing these types of transactions in different areas of the world, specifically the European Union. It will touch on the legal instruments governing Mergers and Acquisitions in the European Union and will challenge the applicability of the fundamental freedoms of the European Union in light of the cross-border Mergers and Acquisitions directives. The paper will challenge the European Court of Justice's approach to the Freedom of Establishment and the application of cross-border M\&As.

Finally, a clear demonstrateion of the fallbacks of the provisions of the Cross-Border Mergers Directives is provided as well as challenging the European legislature's choices in drafting said directives. Unusual discrepancies between the directives and the fundamental freedoms of the European Union are shown, however these two which must always be in line with one another.

Keywords: mergers, acquisitions, cross border, corporate, European Union

Absztrakt: A tanulmány az egyesülések és felvásárlások globális gazdaságban betöltött szerepét vizsgálja. Tárgyalja az ügyletek végrehajtásának kihívásait, előnyeit és kérdéseit a törvényesség, a társadalom és a kultúra szempontjából. Emellett egy empirikus vizsgálatot is tartalmaz, amely az egyesülések és felvásárlások alkalmazását elemzi különböző társadalmi és kulturális munkakörnyezetek jelenlétében.

Az írás kitér arra is, hogy az ilyen típusú ügyleteket milyen jogi eszközökkel szabályozzák a világ különböző területein, különösen az Európai Unióban. Kitekint az Európai Unióban az egyesüléseket és felvásárlásokat szabályozó jogi eszközökre, és megkérdőjelezi az Európai Unió alapvető szabadságainak alkalmazhatóságát a határokon átnyúló egyesülési és felvásárlási irányelvek fényében. A tanulmány vitatja továbbá az Európai Bíróságnak a letelepedés szabadságával és a határokon átnyúló M \& As alkalmazásával kapcsolatos megközelítését.

Végül a cikk bemutatja a határokon átnyúló egyesülési irányelvek rendelkezéseinek hátulütőit, és megkérdójelezi az európai jogalkotó azon döntéseit, melyeket az említett irányelvek kidolgozásakor hozott.

Kulcsszavak: fúziók, felvásárlások, határokon átnyúló, vállalati, Európai Unió 
Debreceni Jogi Múhely 2021. (XVIII.) 1-2.

Debreceni Egyetem, Állam- és Jogtudományi Kar, Debrecen

(University of Debrecen, Faculty of Law, Debrecen)

DOI 10.24169/DJM/2021/1-2/1

\section{Introduction}

Mergers and acquisitions $(\mathrm{M} \& \mathrm{~A}(\mathrm{~s}))$ are a reality in the global economy and have become one of the most effective approaches to corporate restructuring. Cross-border M\&As have become a crucial part of speeding up profitable globalization (Sherman, 2006) and have become increasingly common over the past twenty years. Generally speaking, cross-border business deals amount to approximately one-third of worldwide M\&A activity (Morgan, 2017). This ratio continues to grow as the business continues to grow in capacity. In a world that has become progressively globalized, economies can no longer function in isolation. With market integration constantly on the rise, cross-border M\&As play an important role in expanding and growing the market. However, along with the important role and advantages these transactions inflict comes many legal consequences and implications that usually accompany various types of contractual engagements. Therefore, engaging in cross-border M\&As seems to be a very attractive option for investors seeking out ways to enhance and enlarge the value of their investments.

This paper will discuss challenges that occur while implementing cross-border M\&As and explore the benefits of such transactions focusing on the various issues accompanying cross-border M\&As in terms of society and culture. This paper also contains a case study on how culture can affect a cross-border M\&A involving German and American working relationships. With reference to the possible legal considerations caused by transnational arrangements, this paper will also give an overview of the regulatory framework in which cross-border M\&As exist. The paper will examine how freedom of establishment affects cross-border M\&As in the European Union. The European Commission Merger Regulation provides competition rules and enables the European Commission to stop anti-competitive mergers which unfavourably affects the European Market. In the year 2004, said regulation was reformed in order to meet the challenges associated with competition. The goal is to examine how the reform in the regulation affected cross-border M\&As flowing into European Union Countries.

\section{Social and Cultural Challenges in Cross-Border Mergers and Acquisitions}

National culture is a set of largely implicit and fixed shared values, beliefs, and assumptions that influence the behaviour of humans in a society. According to a KPMG conducted report (PR Newswire, 1999), some studies discovered that the outcome of cross-border M\&A around the world show that $83 \%$ of them fail within three years, mostly as a result of a lack of adaptation towards the cultural context in which an M\&A takes place.

An organizational culture is "the way in which members of an organization relate to each other, their work and the outside world in comparison to other organizations" Dr Geert Hofstede. The important thing to notice is that when integrating, attention to details is essential. A target company might be very financially lucrative but if the way of working does not support a future strategy, it is highly probable that the acquisition will not stand. Taking corporate structure into consideration is one of the most important steps to be taken during M\&As. When companies do not pay attention to differences in conditions in the other country, a 'clash of cultures' will be the result. Therefore, it is essential to conduct culture surveys in order to determine the cultural norms within both businesses and to take into consideration the differences in philosophies, formalities and operating styles. For example, the decision-making process at one of the businesses can be the opposite of the other; the leadership style could either be dictatorial or consultative and the way people work and interact could be formal or informal. 
Debreceni Jogi Múhely 2021. (XVIII.) 1-2.

Debreceni Egyetem, Állam- és Jogtudományi Kar, Debrecen

(University of Debrecen, Faculty of Law, Debrecen)

DOI 10.24169/DJM/2021/1-2/1

\section{Case Study of Cross-Border Mergers and Acquisitions}

\section{Failure due to cultural mismatch - Daimler-Benz \& Chrysler}

General Overview:

In 1998, Daimler-Benz (German) and Chrysler Corporation (American), two of the world's leading car manufacturers, agreed to merge their businesses in what was at the time called a "merger of equals". This merger was one of the biggest cross-border mergers in the automobile industry. The main aim of this merger was to expand the companies geographically and to create a situation where both companies could benefit from shared capacities, infrastructure and facilities.

Conflicts arose in the attempted merger of Daimler Benz and Chrysler had taken place. The reason behind such conflict was the hierarchical approach of Daimler Benz and the poor organizational approach at Chrysler. One of the biggest obstacles this merger faced was of a cultural nature. After the merger was implemented, various cultural differences between the American and German style of management came to light. The Germans entered into this merger with the aim to gain superiority over the Americans which created a struggle for leadership.

Conflicts:

Leadership is one of the most important aspects to be managed during M\&As. When this merger was entered into, the Germans strived to gain leadership over the Americans. This created a big void that reflected on the administration of the new establishment as well as all its employees. Leadership "voids" during M\&A events can negatively impact momentum and destroy value. And worse, it can permanently hobble a "newco" right out of the gate. Your leadership "posture" during an M\&A event should be a carefully planned and coordinated to avoid unexpected results and issues (Whitaker, 2012).

One of the very first basic conflicts that occurred during this transaction was the struggle over the location of the new establishment. Daimler-Benz were not willing to compromise and to change the location of the headquarters of the company and neither were Chrysler Corporation. Another conflict arose when the parties were trying to determine what the name of the new establishment would be. Daimler-Benz claimed that their name had too long of a history to be changed, albeit the Americans have suggested combining both names together so the new establishment would be named "ChryslerDaimler-Benz". Also, work habits between both companies strongly differed. The Americans were used to a dress-down style while the Germans were always formally dressed.

Additionally, there was disagreement in relation to their financial reporting systems which are different in both countries. In the United States, a quarterly based reporting system is followed, whereas, in Germany, the financial reporting system is based on full-year reports. Major losses were projected as a result of this failed merger. In 2007, Chrysler was sold by Daimler-Benz to Cerberus Capital Management for $\$ 6$ billion.

Summing up:

Companies usually tend to dismiss the power of culture while focusing on financial goals. Culture is rigorously linked to behaviours that affect business value. In order for businesses to achieve post-merger objectives, all sides of the merger must be covered and attention should always be paid to the cultural aspects, especially while performing cross-border mergers where culture is always an issues.

What is concluded from the Daimler-Benz \& Chrysler case study is entering into a merger with the intention to dominate will not result in positive outcomes from the transaction. Also, Germans and Americans are two strong cultural societies. Therefore, compromises cannot be expected from them when implementing an M\&A.

On the other hand, properly dealing with culture as a main factor in the M\&A will likely help in reaching positive results and could be an effective instrument for accomplishing post-merger objectives. 
Debreceni Jogi Múhely 2021. (XVIII.) 1-2.

Debreceni Egyetem, Állam- és Jogtudományi Kar, Debrecen

(University of Debrecen, Faculty of Law, Debrecen)

DOI 10.24169/DJM/2021/1-2/1

\section{Global Regulatory Environment}

It is necessary to discuss the regulatory environments that influence M\&As, provided that these transactions usually raise vast legal implications where there is always room for interpretation. Any contractual agreement entered into is influenced by the legal contractual environment in which it is entered into. However, the issue becomes more complex when several legal environments are involved. Furthermore, antitrust (competition) regulations need to be met when structuring M\&A deals as parties are required to be in compliance with the applicable regulations.

\section{Competition Regulation}

The main objective of competition regulations within the scope of Mergers and Acquisitions is preventing corporations from forming monopolies and to maintain healthy competition in the market. It is important to take into consideration the impact of having different competition laws in different jurisdictions as well as the multilateral trade agreements in specific regions such as the European Union. One of the prime concerns arising with M\&As is the extensive regulations on competition law scrutiny which entail excessive costs accompanied with such transitions (Goranova, Dharwadker, Brandes, 2010, p. 1114).

Usually, the competent authorities need to be notified and involved when mergers are proposed. The relevant authorities are delegated to decide whether the deal will be beneficial for the market or not. Upon doing so, the deal is either prohibited or approved. Such approval can either be conditional or unconditional depending on the circumstances of the case. When such a decision is being made, the guidelines referred to are the ones set out by the national laws of the relevant countries (the parties' countries of origin) although best practice principles are being formulated by the International Competition Network as well as the Organization of Economic Co-operation and Development (Galloway, 2009, p. 179).

The idea of converging laws for all relevant jurisdictions is very helpful and offers solutions in terms of following different jurisdictions and having to provide different notifications to all the concerned authorities. (Galloway, 2009, p. 179) However, due to sovereign jurisdictions, states are not obliged to adjust their laws in order to make them less burdensome for corporations to merge and enter into transactions.

There has been very little effort to set precise outlines for determining the materiality of a jurisdictional nexus. (Galloway, 2009, p. 179) The International Competition Network report, (2008) suggested introducing flexibility for future reform by using inflation indices or by providing for the ability to make changes through non-legislative procedures. The aim of the recommendation is to reduce the costs of public and private resources in connection with the notification and review of mergers that are unlikely to raise any competition concerns.

\section{Foreign Direct Investment Laws and Protectionism}

A strong investment system has been developed with reference to the protection of investors (Sauvant, 2009). The investment environment has been very welcoming to foreign investments however, negative changes to national laws have been rising which resulted in a less welcoming environment for investors and all of that has been occurring in the name of protectionism, which can be linked to public policy.

There are two protectionism structures in the scope of Foreign Direct Investment. One is inward Foreign Direct Investment, where new laws and measures are taken in order to discourage foreign investments, while the other is outward Foreign Direct Investment where domestic enterprises are required to expel their assets to the home country. Sauvant, 2009, p. 7.)

However, not all measures that are taken in the interest of public policy particularly qualify as protectionism, even if such measures result in a less approachable environment for investors. It just happens that the investment laws of some countries do not allow all investment transactions even if they do not impose a negative impact on competition (Nourry, Jung, 2012). The reason behind these prohibitions is usually related to public policy objectives. At many occasions, this kind of protectionism is accompanied with justifications relating to economic downturns. However, it is surprising that many regulatory changes took place prior to 
Debreceni Jogi Múhely 2021. (XVIII.) 1-2.

Debreceni Egyetem, Állam- és Jogtudományi Kar, Debrecen

(University of Debrecen, Faculty of Law, Debrecen)

DOI 10.24169/DJM/2021/1-2/1

the occurrence of these economic downturns (Sauvant, 2009). These measures are taken by governments for two main reasons: the first is to be able to stop undesirable Foreign Direct Investment, and the second is for balancing a global investment regime. Sauvant, 2009, p. 13.) Therefore, "national security" is just a criterion used to grant legislators full discretion when drafting and enforcing laws.

The Foreign Trade and Payment Act (the Act) applied in Germany provides certain restrictions and obligations on foreign trade transactions in order to ensure national security stability. The Act provides the following:

(1) In foreign trade and payments transactions, legal transactions and actions can be restricted and obligations to act can be imposed by ordinance, in order

1. to guarantee the essential security interests of the Federal Republic of Germany,

2. to prevent a disturbance of the peaceful coexistence of nations or

3. to prevent a substantial disturbance to the foreign relations of the Federal Republic of Germany,

4. to guarantee the public order or security of the Federal Republic of Germany within the meaning of Articles 36, 52(1) and Article 65(1) of the Treaty on the Functioning of the European Union or

5. to counteract a danger to the coverage of vital needs in Germany or in parts of Germany and thereby to protect the health and life of human beings in accordance with Article 36 of the Treaty on the Functioning of the European Union (Foreign Trade and Payment Act, 2013).

The Act also provides that any acquisition made by entities that do not belong to the European Union or the European Free Trade Association countries must be reviewed if it is believed that public security could be at stake.

There has also been an update in policy for foreign direct investment by the Ministry of Commerce in the People's Republic of China. The Chinese policy makers have passed a regulation requiring the approval of the relevant authorities on transactions which entail non-Chinese investors wishing to take over domestic entities. It is seen as though such transactions have bearing on the country's national security or it involves taking over well-known Chinese trademarks.

The abovementioned examples seem to show a few features in regulatory development. One of the common concerns amongst regulators is the protection of national security, and when trying to protect national security, governments seem to pay concern to whether the motives behind these transactions are purely economic or involve political direction.

Considering the changes occurring in the world we currently live in, policy makers need to amend laws and regulations so that they adapt to such changes. A number of past regulatory changes seen in recent years reflect the needs for governments to protect and maintain their national interests. However, given the broad understanding of concepts such as "national security", "national interests" and "public policy", it often becomes difficult to interpret what measures are taken in the names of such concepts and what others are discriminatory and protectionist.

Application of the Freedom of Establishment to the Cross-Border Mergers Directive in the European Union

It is essential that the European Union fundamental freedoms are reached through the applicable regulations and directives. Precisely, this analysis is to ensure that companies are able to exercise their right of freedom of establishment by being able to establish themselves in member states. Said exercise must be accompanied with the necessary flexibility to form corporate restructuring without incurring extensively high costs and burdensome formalities. 
Debreceni Jogi Múhely 2021. (XVIII.) 1-2.

Debreceni Egyetem, Állam- és Jogtudományi Kar, Debrecen

(University of Debrecen, Faculty of Law, Debrecen)

DOI 10.24169/DJM/2021/1-2/1

\section{Legal Instruments Relevant to Mergers}

Early harmonizing measures provided some necessary prerequisites for the implementation of a CrossBorder Mergers directive which was only adopted later in time. The First Company Law Directive (68/151/EEC) and the Second Company Law Directive (77/91/EEC) help provide security of legal transactions and equality in the treatment of creditors and shareholders which in turn, achieved equality of competition in the European Union. The disclosure of financial information which is very important for corporate restructuring is regulated under the fourth, seventh and eighth company directives. These directives help provide a safe environment for legal relations and cross-border investments.

The Third Company Law directive (1978) establishes an outline for local mergers whilst the sixth Company Law directive regulates the division of local companies. As such, the third and sixth Company Law directives play a major role in cross-border investments within the internal market as they discourage physiological obstacles by encouraging foreign investors to establish corporations in other member states (Habersack, 2000). Furthermore, these directives play a very important role in cross-border mergers as they stimulate harmonization within laws governing domestic mergers and domestic divisions of companies.

The importance of the third and the sixth Company Law directives for cross-border activity is that the latter provides that any company taking part in cross-border mergers must comply with the provisions of the national law and the harmonized national rules on mergers. Although drafting cross-border mergers directives and regulations encountered several difficulties and delays, the third Company Law directive concerning domestic mergers of public limited liability companies was adopted in 1978.

The main topographies of the third Company Law Directive on domestic mergers are as follows:

- all assets and liabilities are transferred by operation of the law,

- the disappearance of all companies whose assets and liabilities are transferred,

- shareholders of the disappearing companies become shareholders of the acquiring one (Wouters, Schneider, 1995, p. 146),

- a qualified majority general meeting of all the participating companies (apart from the newly created one), and

- other provisions on creditor protection, supervised by a national authority (Rickford, 2005, p. 1393).

The third company law directive gives the discretion to Member States to either apply these provisions or apply a more lenient version of them. Alternatively, the acquiring company could be a newly formed company in which case the merger would be called 'a merger by formation of a new company'. In case the acquiring company is an existing company, the merger would be called 'a merger by acquisition'. These legal instruments on local mergers are not only vital for the harmonization of national laws; they also play an important role in the preparation of the harmonization of cross-border mergers.

The implementation of the cross-border mergers directive required coordination of national company rules on mergers so that they would then be used as a point of reference through the operation of cross-border mergers.

The Third Council Directive 78/855/EEC and the Sixth Council Directive 82/891/EEC have given a preparatory ground for the adoption of the Cross-Border Mergers Directive by means of harmonization of national rules which are essential to cross-border transactions and by contributing to the legal framework of corporate restructuring. 
Debreceni Jogi Múhely 2021. (XVIII.) 1-2.

Debreceni Egyetem, Állam- és Jogtudományi Kar, Debrecen

(University of Debrecen, Faculty of Law, Debrecen)

DOI 10.24169/DJM/2021/1-2/1

\title{
The European Court of Justice's Approach to the Freedom of Establishment and its application to Cross-Border Mergers
}

Prior to the adoption of cross-border mergers directives and regulations, A German company (SEVIC) tried to merge with a Luxembourgish company (Security Vision SA), with absorption of the latter by the former. However, this case was brought to the European Court of Justice as German laws only slowed domestic mergers and not cross-border mergers. Therefore, the merger could not be completed. In 2005, the European Court of Justice ruled:

\begin{abstract}
"Registration in the national commercial register of the merger by dissolution without liquidation of one company and transfer of the whole of its assets to another company from being refused in general in a Member State where one of the two companies is established in another Member State, whereas such registration is possible, on compliance with certain conditions, where the two companies participating in the merger are both established in the territory of the first Member State."
\end{abstract}

The ruling in the SEVIC case discussed the subject of a cross-border merger supported directly by the freedom of establishment (Hansen, 2007). It also tackled the issue of prohibition of cross-border mergers by Member States. Cross-border mergers are advantageous to the European Union as an alternative to other costly and complex transactions that achieve similar results (Schindler, 2006).

In this case, the European Court of Justice stresses the importance of mergers as an important form of corporate restructuring and subsequently, as an exercise of freedom of establishment. It declares that mergers constitute an effective means of transforming companies, making it possible for corporations to operate within a single framework and to pursue particular activities in new forms without interruption, thereby decreasing the difficulties, time and costs associated with other forms of corporate consolidation.

However, The German government claimed that cross-border mergers are not covered by freedom of establishment, because the merging company would lose its legal personality and the freedom of establishment cannot be interpreted as granting companies the right to dissolve themselves by taking part in cross-border mergers. These arguments were rebutted as it was opined that, throughout the early stages of the merger up to the registration thereof, both companies existed and operated as two separate entities, entirely capable of entering into the merger. However, when the merger is completed, one of the two persons ceases to exist. Until such a point in time, this is not the case, because, if the operation has not been completed, the company which was to have been incorporated would continue to exist as an autonomous legal person. Thus, the parties to a cross-border deal are protected by the freedom of establishment.

The European Court of Justice concluded that cross-border merger operations, like other company transformation operations, respond to the need for cooperation between companies established in different Member States. They create particular methods of exercise of the freedom of establishment, significant for the appropriate operations of the internal market, and are therefore amongst those economic activities in respect of which Member States are required to comply with the freedom of establishment laid down by Art. 43 EC Treaty. Aside from the exercise of the right of secondary establishment by forming or acquiring a subsidiary in the host State, a company can now acquire another company in another Member State through merger and then operate a branch in the latter Member State. The understanding of the freedom of establishment is widened, because the free access to the regions of other Member States through the establishment of subsidiaries is not enough for the exercise of the freedom of establishment and does not consume its content. Corporate restructuring within the internal market is associated with approved methods for the implementation of the freedom of establishment. One of these approved methods for the implementation of the freedom of establishment is the ability to conduct a merger. Hence, this approach widens the previous understanding of the right of establishment.

The case law on companies and the right of establishment are connected to the secondary European Union legislation in directives and regulations. The key purpose of the secondary legislation is to materialize and give effect to the fundamental freedoms in the EC Treaty. The case law of the Court of Justice develops the content of the fundamental freedoms and the ways in which they are given effect, and defines the legal basis for the secondary legislation in directives and regulations. The provisions of directives and regulations must comply with the freedoms as they are developed in the case law. In the SEVIC case, the European Court 
Debreceni Jogi Múhely 2021. (XVIII.) 1-2.

Debreceni Egyetem, Állam- és Jogtudományi Kar, Debrecen

(University of Debrecen, Faculty of Law, Debrecen)

DOI 10.24169/DJM/2021/1-2/1

of Justice had confirmed its stance towards the relationship between harmonization and the fundamental freedoms. Paragraph 26 of the judgment stated:

"Whilst Community harmonization rules are useful for facilitating cross-border mergers, the existence of such harmonization rules cannot be made a precondition for the implementation of the freedom of establishment laid down by Articles 43 EC and 48 EC Treaty". Where the legislative process has not led to agreement on outcomes, legislation may be superseded by the case law, disregarding national law (Papadopoulos, 2012).

\section{Examining the Cross-Border Mergers Directive in light of the Freedom of Establishment}

\section{Methods of Conducting a Merger}

Article 119 (2) of DIRECTIVE (EU) 2017/1132 of the European Parliament and of the Council of 14 June 2017 relating to certain aspects of company law provides:

"(a) one or more companies, on being dissolved without going into liquidation, transfer all their assets and liabilities to another existing company, the acquiring company, in exchange for the issue to their members of securities or shares representing the capital of that other company and, if applicable, a cash payment not exceeding $10 \%$ of the nominal value, or, in the absence of a nominal value, of the accounting par value of those securities or shares; or

(b) two or more companies, on being dissolved without going into liquidation, transfer all their assets and liabilities to a company that they form, the new company, in exchange for the issue to their members of securities or shares representing the capital of that new company and, if applicable, a cash payment not exceeding $10 \%$ of the nominal value, or in the absence of a nominal value, of the accounting par value of those securities or shares; or

(c) a company, on being dissolved without going into liquidation, transfers all its assets and liabilities to the company bolding all the securities or shares representing its capital."

Presumably, the resulting company of a cross-border transaction would be a company established in a new jurisdiction different that the jurisdictions of either of the companies entering into the transaction. This in itself results in migration of businesses of the participating companies and entails an exercise of the freedom of establishment (Rickford, 2005, p. 1393).

Another method of conducting a merger might occur after a successful takeover bid. This could result in the transformation of the offeree company into a 100\% owned subsidiary. An individual or company seeking to acquire a controlling holding that confers influence over a target company would also fall within the scope of the right of establishment (Ugliano, 2007, p. 599). Hence, the conduct of a takeover bid involves an exercise of the right of establishment. The European Union market for corporate control is a part of the internal market, and thus its integration is a prerequisite for the integration of the other. Therefore, this method of conducting a merger constitutes not only an exercise of the right of establishment itself, but also facilitates the exercise of the freedom of establishment through a takeover bid by providing an additional subsequent tool of corporate restructuring. Thus, an exercise of the freedom of establishment through a takeover bid could be followed by an exercise of the freedom of establishment through a merger.

The Principle of Equal Treatment

The equal treatment approach is followed by the Cross-Border Mergers Directive. An additional requirement which must be fulfilled by the participating companies is that cross-border mergers shall only be possible between types of companies which may merge under the national law of the relevant Member States. This acknowledges the significance of the principle of equal treatment which constitutes the foundation of the fundamental freedom of establishment. This requirement is quite obscure because it does not clarify what would happen in the case where, in one Member State, a merger is allowed between a public and a private company, even though this transaction is not allowed in another Member State. Is it possible for a private company located in the former Member State to merge with a public limited company located in the latter Member State? 'The use of plural in the phrase 'relevant Member States' could imply that all the Member States concerned must allow mergers of the relevant type. It seems difficult to accept that the private company from the prior Member State acquires the right to disregard the company law provisions of the latter Member State and to merge with one of its public companies. 
Debreceni Jogi Múhely 2021. (XVIII.) 1-2.

Debreceni Egyetem, Állam- és Jogtudományi Kar, Debrecen

(University of Debrecen, Faculty of Law, Debrecen)

DOI 10.24169/DJM/2021/1-2/1

In case national company law does not grant the right to a company to merge with another domestic company, the company will not have the right to participate in a cross-border merger. The national legislature enjoys the discretion to prohibit a type of company from participating in cross-border mergers by repealing its competence to merge with another domestic company. However, this scenario is not so probable, because those Member States which are not keen on cross-border mergers allow domestic mergers nonetheless, because company and employment law interests are not endangered in such mergers. It would be interesting to see how a possible legislative initiative like this would interact with SEVIC, which declared that cross-border mergers fall within the protective scope of the fundamental freedom of establishment.

\section{The Relevant Regulatory body}

EU Directive 2017/1132 of the European Parliament and of the Council of 14 June 2017 identifying with specific parts of Company law went into power on 20 July 2017. The point of the Directive is to solidify and systematize the following EU mandates:

- Sixth Council Directive 82/891/ECC of 17 December 1982 concerning the division of public limited liability companies;

- Eleventh Council Directive 89/666/ECC of 21 December 1989 concerning disclosure requirements in respect of branches opened in a Member State by certain types of company governed by the law of another State;

- Directive 2005/56/EC of 26 October 2005 on cross-border mergers of limited liability companies;

- Directive 2009/101/EC of 16 September 2009 on coordination of safeguards which, for the protection of the interests of members and third parties, are required by Member States of companies within the meaning of the second paragraph of Article 48 of the Treaty, with a view to making such safeguards equivalent;

- Directive 2011/35/EC of 5 April 2011 concerning mergers of public limited liability companies; and

- Directive 2012/30/EU of 25 October 2012 on coordination of safeguards which, for the protection of the interests of members and others, are required by Member States of companies within the meaning of the second paragraph of Article 54 of the Treaty on the Functioning of the European Union, with respect to the formation of public limited liability companies and the maintenance and alteration of their capital, with a view to making such safeguards equivalent.

The presentations of the Directive underline the requirement for explicit orchestrated protections to be set up, especially as for public restricted obligation organizations, eminently due to the regular cross-line character of their exercises and the prevalent person of such organizations in the economy of the Member States.

The Directive explicitly sets down measures concerning:

- the coordination of public protections regarding the arrangement of public restricted risk organizations and the support and adjustment of their capital, and as for revelation, legitimacy of commitments went into by, and the nullity of, organizations restricted by shares or in any case having restricted obligation, with the end goal of making such shields same;

- the revelation prerequisites concerning branches opened in a Member State by explicit sorts of organizations administered by the law of another State, to stay away from variations in the security of investors and outsiders;

- the assistance of consolidations and cross-line consolidations of restricted responsibility organizations; and

- the division of public restricted risk organizations to guarantee that investors of the organizations 
Debreceni Jogi Múhely 2021. (XVIII.) 1-2.

Debreceni Egyetem, Állam- és Jogtudományi Kar, Debrecen

(University of Debrecen, Faculty of Law, Debrecen)

DOI 10.24169/DJM/2021/1-2/1

included remain satisfactorily educated.

\section{Conclusion}

Given the current economic climate, the future of cross-borders mergers and acquisitions is indeterminate. Nevertheless, with developing markets still showing room for growth, opportunities do exist for foreign investment to play a big role in growing economies. As long as national regulators and policy makers do not adopt antagonistic protectionist laws which would hinder foreign investment and cross-border M\&As, thus hindering market integration as a whole, there is hope for transnational M\&A activity yet.

As it relates to obstacles in relation to cross-border M\&As and specifically, the Daimler-Benz and Chrysler Corporation merger, what is concluded is entering into a merger with the intention to dominate will not result in positive outcomes from the transaction. Furthermore, Germans and Americans are two strong cultural societies. Therefore, compromises cannot be expected from them when implementing an M\&A.

The most important provisions of the Cross-Border Mergers Directive were analysed in the light of the freedom of establishment, as was interpreted by the European Court of Justice's case law. It was observed that the contribution of some provisions of this Directive to freedom of establishment is questioned. The choices of the European legislature are definitely open to criticism. Some categories of companies within the scope of Art. 48 EC Treaty (Art 54 TFEU) do not fall clearly within the scope of the 10th Company Law Directive. The restricted scope of the 10th Company Law Directive is clearly not in compliance with the freedom of establishment, as well as with the aims of market integration in general. The principle of equal treatment is quite unclear because it does not clarify what would happen in the case where, in one Member State, a merger is allowed between a public and a private company, even though this transaction is not allowed in another Member State. Additionally, the disadvantages of optionality as established by the 3rd Company Law Directive will also now be transferred to the field of cross-border mergers. Creditor protection and protection of minority shareholders are deficient as regulated currently by the Cross-Border Mergers Directive. This liberalization of the consideration provisions is something quite positive but it is still open to criticism. An examination of the relationship between SEVIC and the Cross-Border Mergers Directive reveals additional problematic areas. Nevertheless, these deficiencies of the Cross-Border Mergers Directive are not something extremely worrying within the framework of the internal market. A provision of secondary EU law could infringe the freedom of establishment, but this infringement would be accepted as a justified one (Papadopoulos, 2012). 
Debreceni Jogi Múhely 2021. (XVIII.) 1-2.

Debreceni Egyetem, Állam- és Jogtudományi Kar, Debrecen

(University of Debrecen, Faculty of Law, Debrecen)

DOI 10.24169/DJM/2021/1-2/1

\section{References}

Andrew, J.S. and Milledge, H.A., 2006. Mergers and Acquisitions from A to Z. From A to.

Morgan, J.P., 2017. Mergers and Acquisitions Global Outlook, Finding Opportunities in a Dynamic Market.

Goranova, M., Dharwadkar, R. and Brandes, P., 2010. Owners on both sides of the deal: Mergers and acquisitions and overlapping institutional ownership. Strategic Management Journal. https://doi.org/10.1002/smj.849

Galloway, J., 2009. Convergence in international merger control. The Competition Law Review, 5(2)

ICN (2008) "Setting Notification Thresholds for Merger Review" Report to the ICN Conference

Sauvant, K.P., 2009. FDI Protectionism is on the Rise. The World Bank. https://doi.org/10.1596/1813-

9450-5052

Nourry, A. and Jung, N., 2012. EU State Measures Against Foreign Takeovers

Foreign Trade and Payment Act of (2013)

Ministry Of Commerce - Republic Of China "Interim Provisions on Mergers and Acquisitions of Domestic Enterprises by Foreign Investors"

Rickford, J., First Council Directive 68/151/EEC of 9 March 1968

Third Council Directive 78/855/EEC of 9 October 1978 based on Art. 54 (3) (g) of the Treaty concerning mergers of public limited liability companies.

Habersack, M., 2000. Vanessa Edwards, EC Company Law, Oxford EC Law Library, edited by FG Jacobs; Oxford, Clarendon Press, 1999, lxxi+ 431 pages, ISBN 0-19-825993-X. European Business Organization Law Review. https://doi.org/10.1017/S1566752900000100

Wouters, J and Schneider H, Current Issues of Cross-Border Establishment of Companies in the European Union (1995) (p 146).

Rickford, J., 2005. Proposed Tenth Company Law Directive on Cross Border Mergers and Its Impact in the UK.

Hansen, L.L., 2007. Merger, Moving and Division Across National Borders-When Case Law Breaks through Barriers and Overtakes Directives.

Schindler, C.P., 2006. Cross-Border Mergers in Europe-Company Law is catching up!-Commentary on the ECJ's Decision in SEVIC Systems AG. https://doi.org/10.1515/ECFR.2006.004

Papadopoulos, T., 2012. The magnitude of EU fundamental freedoms: application of the freedom of establishment to the cross-border mergers directive. European Business Law Review. 
Debreceni Jogi Múhely 2021. (XVIII.) 1-2.

Debreceni Egyetem, Állam- és Jogtudományi Kar, Debrecen

(University of Debrecen, Faculty of Law, Debrecen)

DOI 10.24169/DJM/2021/1-2/1

Ugliano, A., 2007. New Cross-Border Merger Directive: Harmonisation of European Company Law and Free Movement, The. Eur. Bus. L. Rev. 